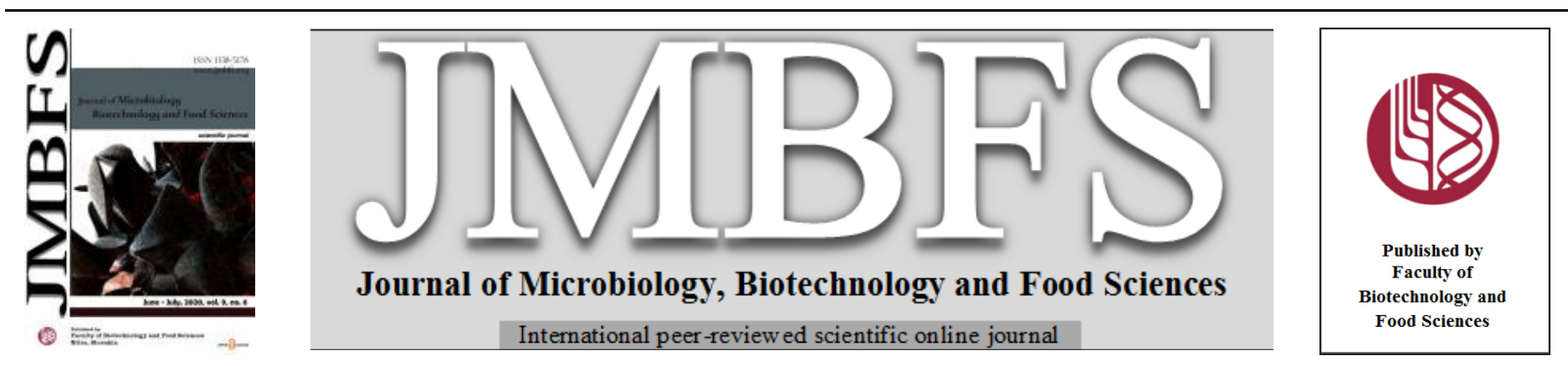

\title{
INCLUSION BODIES IN BIOTECHNOLOGY
}

\author{
Romana Köszagová ${ }^{1,2}$, Jozef Nahálka ${ }^{1,2}$
}

Address(es): Ing. Romana Köszagová,

${ }^{1}$ Slovak Academy of Sciences, Institute of Chemistry, Dúbravská cesta 9, 84538 Bratislava, Slovak Republic.

${ }^{2}$ Slovak University of Agriculture, Center of excellence for white-green biotechnology, Tr. A. Hlinku 2, 94976 Nitra, Slovak Republic.

*Corresponding author: chemrore@savba.sk

doi: 10.15414/jmbfs.2020.9.6.1191-1196

ARTICLE INFO

Received 4. 12. 2019

Revised 5. 2. 2020

Accepted 19. 2. 2020

Published 1. 6. 2020

$\overline{\frac{\text { Review }}{\text { open } \bigodot_{\text {access }}}}$

\begin{abstract}
Protein aggregation is commonly observed phenomenon occurring during production of recombinant proteins in genetically engineered organisms over-expressing foreign genes. Aggregation of such recombinant proteins often leads to the formation of insoluble protein clusters named inclusion bodies (IBs). Although usually considered as waste by-products of protein production, over the last decade, this general misconception has been questioned by various studies. Gradual understanding of the structural, molecular and physiological features has revealed promising potential of these so far undesirable cellular products. In the present review we summarize basic characteristics of IBs, their use in antimicrobial peptides production and in various biotechnological fields, including tissue engineering, drug delivery and biocatalysis.
\end{abstract}

Keywords: inclusion bodies, protein aggregation, biotechnology, antimicrobial peptides, biomedicine

\section{INTRODUCTION}

Biotechnology is a conquering and extremely dynamically developing area which applications are so wide that practically nowadays every industry uses biotechnology in some form. Protein production (antimicrobial peptides/proteins, enzymes, hormones, antigens, drug carriers etc.) present one of the main areas of interest in modern biotechnology. The long-term goal is to produce soluble proteins in as large quantity as possible and at the same time eliminate the formation of inclusion bodies (IBs) that have been for long time considered as waste and dysfunctional byproducts of protein production. However, production of these soluble proteins is often challenging and additional steps of inclusion bodies recovery, such as solubilization and refolding are often needed. In addition, it is usually necessary to evaluate individual expression and purification protocols for each protein and yet often a portion of proteins still stay misfolded and insoluble (Hadj Sassi et al., 2017, Upadhyay et al., 2016, Mohammadian et al., 2017). On the contrary, in recent years, many studies have been increasingly proving that IBs can retain their biological activity, which has led some scientists to concentrate their efforts on the development of methods for production of pure biologically active IBs (Nahalka et al., 2008, Huang et al., 2013). Due to their structural and functional properties IBs can be also considered as naturally immobilized enzymes or as nanomaterials, which allows their easy recycling (Diener et al., 2016, Nahalka et al., 2006). Although IBs also have to be isolated and purified, these protocols are much simpler than those used in the production of soluble proteins. These are just a few of the characteristics that make IBs ideal materials for many biotechnology fields.

\section{IBS PROPERTIES}

Inclusion bodies present protein aggregates accumulating during protein overexpression, or under stress conditions, such as therma (de Groot and Ventura, 2006), $\mathrm{pH}$ (Castellanos-Mendoza et al., 2014) or oxidative stress (Grune, et al., 2004). Incorrect translation or mutations in RNA/DNA can also result in the formation of IBs (Kopito, 2000). Moreover, domains and fusion tags that can drive active proteins into IBs are nowadays widely used (Wang et al., 2015, Wu et al., 2011). These protein aggregates can be formed in the cell cytoplasm and/or periplasm (Arié et al., 2006, Miot and Betton, 2004) and consist of different conformational populations, including amyloid-like, misfolded- and native-like structures, which are present in different ratios (Wang, 2009, Sabate $\boldsymbol{e t}$ al., 2010). In general, IBs are highly hydrated and porous proteins with a diameter in the range of 0.2 to $1.2 \mu \mathrm{m}$ (Margreiter et al. 2008, Carrio et al., 2005). There are several studies that describe shape of IBs usually as cylindrical, spherical or elliptical aggregates (Bowden et al., 1991, Garcia-Fruitos et al., 2010). The surface of IBs varies from rough, with regular folds to smooth and in transmission electron microscopy, they appear as electrondense deposits. Size, shape and other characteristics of IBs are associated with the type of host organism and culture conditions (Bowden et al., 1991).

As mention above there are many factors that influence biophysical/chemical properties and the composition of IBs. However, it is generally proven that IBs consist predominantly of the recombinant product (Neubauer et al.2006). IBs preparations usually contain some another cellular proteins (ribosomal subunit proteins, membrane proteins etc.) and small amount of other macromolecules, such as nucleic acids and lipids (Fahnert et al., 2004).

\section{IBS PRODUCERS}

IBs can be found in both, prokaryotic (Escherichia coli and lactic acid bacteria LAB) and eukaryotic (yeast, microalgae, insect, mammalian cells etc.) cells. These aggregates are designated in eukaryotic cells as aggresomes and, unlike prokaryotic cells, also contain chaperones, chaperonins residues and proteasome subunits (Kopito, 2000, Markossian and Kurganov, 2004). Bacteria, especially Gram-negative bacterium E. coli, has become the most popular expression systems for the production of recombinant proteins due to their rapid growth, well characterized genetics and high yield on inexpensive substrates (Villaverde and Carrio, 2003, Rinas et al., 2017, Peternel and Komel, 2011). LAB, particularly Bacillus subtilis and Lactococcus lactis, has been shown to be an attractive alternative for production of membrane proteins (Boutigny et. al., 2015) and protein-based nanomaterials (Cano-Garrido et. al. 2016). The main advantage of LAB is that, unlike E. coli, they do not contain endotoxins in their membrane and are classified as generally recognized as safe (GRAS) organisms. Despite the very wide use of prokaryotic systems, there are a number of examples where they could not be used to produce complex functional eukaryotic proteins due to their inability to post-translational modification. Yeasts Pichia pastoris (Rueda et al., 2016) and Saccharomyces cerevisiae (Hou et al., 2012) present the most popular recombinant protein expression systems among eukaryotic organisms. It is because of their several advantages, including posttranslational modifications ability, rapid growth, and especially their ability to secrete proteins to the extracellular medium. Over the past few years, microalgae have received increased attention as an alternative expression system suitable for the production of valuable products, such as therapeutics proteins, biofuels and polysaccharides The most commonly used microalgae species are Chlorella, Haematococcus and especially Chlamidomonas (Ch. reinhardrii) (Gong et al., 2011, Spolaore et al., 2006). The main advantages of using microalgae are their high productivity, cost- 
effectiveness and possibility to genetically transform their nuclear and also chloroplast genomes (Manuell et al., 2007, Doron et al., 2016). Insect cells perform most of the posttranslational modifications present in mammalian proteins, and therefore the use of bacilovirus-insect cell expression system has become a common alternative for production of recombinant proteins (Kost $\boldsymbol{e} t$ al., 2005, Contreras-Gómez et al., 2014). Correct protein folding, posttranslational modifications, and product assembly are main advantages of usage mammalian cells as expression systems (Nettleship et al., 2010, Baldi $\boldsymbol{e t}$ al. 2007). CHO (Chinese hamster ovary), HEK-293 (Human embryonic kidney) and NS0 (mouse myeloma) cells have become the most commonly used mammalian cell lines and are used to produce numbers of biopharmaceutical products (Khan, 2013).

Although most misfolded and aggregated proteins in the mammalian cell are usually degraded by various proteolytic systems (ubiquitin -proteasome system, chaperon mediated autophagy and macroautophagy), some of them are resistant to all known proteolytic mechanisms. The accumulation of inclusion bodies or extracellular plaques is linked to many protein misfolding disorders, including at least 30 different human diseases, such as Alzheimer's disease, Parkinson's disease, Huntington's disease and transmissible spongiform encephalopathies. Most of these diseases spread rapidly from a small initial affected region to surrounding areas due to the ability of the aggregates to pass from cell to cell along connected networks. These protein aggregates usually consist of $\beta$-sheetenriched fibrillary structures, termed amyloids, which are $0.1-10 \mu \mathrm{m}$ long and about $10 \mathrm{~nm}$ wide. Conformation of $\beta$-sheets is stabilized by intermolecular interactions, leading to the formation of oligomers, proto-fibrils and fibrils. There is now increased understanding of the amyloid fibril formation, which may prove to be essential in the development of rational therapeutics. The use of bacteria, which express amyloid-like bacterial intracellular aggregates, as model system is one of the approaches to characterize how and when protein aggregates form inside the cell (Ciechanover and Kwon, 2017, Moreno-Gonzalez and Soto, 2011, Ciechanover and Kwon, 2015, Ross and Poirier, 2004).

\section{IBS AND THE ANTIMICROBIAL PEPTIDES PRODUCTION}

Antimicrobial peptides and proteins (AMPs) are usually relatively small (10-100 amino acids), positively charged amphiphilic molecules. AMPs can be found in various organisms, including mammals, plants, invertebrates and prokaryotes. Many different kinds of AMPs have been identified in recent years, indicating their importance in the innate immune system. These antimicrobial molecules can be expressed continuously or the expression can be induced by infection, inflammation or injury (Quinn et al., 2008, Steinstraesser et al., 2008, Zhang and Gallo, 2016). Despite their similar general properties, most of the folded AMPs identified to date can be classified into four groups based on their secondary structure: $\alpha$-helical, $\beta$-stranded, $\beta$-hairpin (loop), and extended (Jenssen et al., 2006, Bahar and Ren, 2013). The most common are amphiphilic peptides with two to four $\beta$-sheets (bactenecins and defensins) or peptides with amphipathic $\alpha$-helices (magainin and human cathelicidin peptide LL37). According to the target organism, AMPs can be categorized into four main groups: antiviral, antibacterial, antifungal and antiparasitic peptides (Jenssen $\boldsymbol{e}$ al., 2006, Bahar and Ren, 2013). So far the best-studied group are cationic antibacterial AMPs where their ability to kill bacteria usually depends on their interaction with bacterial membranes. Positive charge, hydrophobicity (high ratio of hydrophobic amino acids) and flexibility (the ability of protein to change conformation from soluble to membrane-interacting conformation) allows AMP to selectively bind to negatively charged bacterial membrane. Binding of AMPs to the bacterial membrane leads to formation of pores and disruption of bacterial membrane which is followed by the collapse of the transmembrane electrochemical gradient and microbial cell death. Alternately, they may penetrate membrane without any damage, but they kill bacteria by inhibiting some important pathways inside the cell. For example, AMPs can interact with DNA, RNA or protein synthesis, protein folding, and cell wall synthesis (Nguyen et al., 2011, Brogden, 2005). It was originally thought that killing of cells was the only mechanism of action of AMPs, bud there is increasing evidence now that AMPs can also recruit and activate immune cells and even display antiviral (Gwyer et al., 2013) and anticancer (Felício et. al., 2017) activities.

In recent years, thanks to the spread of multi-drug resistant microbes ("superbugs"), the research of the AMPs attracted much more attention as promising candidates for the development of alternative antibiotics (Aoki and Ueda, 2013). However, to investigate the structure and mechanism of action of specific AMP it is necessary to obtain a significant amount of this molecule. Isolation and purification from natural sources (epithelial or plant cells) is usually expensive and tedious task. Although, chemical synthesis can be used to produce certain amounts of this peptides (Harris et al., 2014), structural determination, toxicity testing and preclinical studies usually require larger amounts of material. Furthermore, if AMPs are longer than 50 amino acids or contain more than one disulfide bond, production costs will increase substantially. In general, heterologous expression of AMPs provides a means for economical protein production. E. coli and yeast are the most commonly used recombinant systems. However, use of $E$. coli as an expression system to produce AMPs faces two main challenges. First, AMPs are potentially toxic to the producing host, and second, small size of these molecules makes them especially susceptible to degradation. Expression of AMPs in fusion with carrier proteins $(\mathbf{L i}, \mathbf{2 0 1 1})$ or use of specialized E. coli strains, which carry mutations making them more tolerant present two main strategies that effectively overcomes these obstacles. Although some fusion proteins provide production of soluble proteins (thioredoxin (Bogomolovas et al., 2009), glutathione transferase and small ubiquitin-related modifier (Li et. al., 2011, Ma et. al., 2012)), others promote the formation of inclusion bodies. Moreover, compared with soluble fusion, expression of AMPs in the form of IBs is believed to be more efficient than soluble fusion in masking the peptides' toxic effects and protecting them from proteolytic cleavage. Other advantages of protein production in the insoluble form are high rates of expression and easy collection of IBs by differential centrifugation after cell disruption. In the following section, we will focus on expressing AMPs as fusion proteins by genetically linking the AMPs to fusion protein tags with high tendency to form IBs.

There is several fusion partners that have been specially designed to pull-down peptides into inclusion bodies and selection of the appropriate one is important for effective solving of toxicity, solubility and purification challenges. Most widely used tags are PurF fragment (amidophosphoribosyltransferase), ketosteroid isomerase (KSI), autoprotease $\mathrm{N}^{\mathrm{pro}}$ and baculoviral polyhedrin. These tags can also trigger an undesirable immune response so after expression of IBs they must be removed from therapeutic proteins. There are two main methods used to remove tags: use of specific endoproteases that recognize a specific linker sequence or use of intein self-cleavage systems such as tailor-made $\mathrm{N}^{\text {pro }}$ mutant called EDDIE (Achmüller et. al. 2007, Kaar et. al., 2009).

To avoid the harmful effects on host system (E. coli) Lee et al. (2000) choose polypeptide F4 aggregation-promoting carrier (fragment of purF gene) to form inclusion bodies. They successfully used this expression system to produces seven different kinds of AMPs (MSI-344, bombinin, melittin , indolicidin , PGQ ,tachyplesin I and XPF), while the resulting expression levels were about 25-30 $\%$ of total cell proteins. KSI present another carrier protein with high inclusion body-forming tendency and is a commonly used affinity tag for expression and purification of short peptides. For example, KSI-DCD1-His6Tag protein expression system was successfully used to produce dermcidin in the form of IBs (Čipáková et al., 2005). Dermcidin, anionic antimicrobial peptide, which has been discovered in human sweat, displays antimicrobial activity against pathogenic microorganisms such as Staphylococcus aureus and Candida albicans. Amparyup et. al (2008) successfully cloned and characterized the full length cDNA and genomic organization of a crustin-like antimicrobial peptide (Crus-likePm). They cloned mature Crus-likePm from haemocytes of Penaeus monodon into the hexahistidin tag and used Vibrio harveyi as host organism. In this expression system rCrus-like $P m$ was found in both inclusion bodies and soluble fraction, however the purity of protein was higher when purified from IBs. The purified recombinant Crus-likePm protein was highly active in inhibiting the growth of Gram-positive and Gram-negative bacteria including $V$. harveyi. Baculoviral polyhedrin (Polh) is the major component of the virus occlusion body known as a polyhedral that protect the virus particle from physical and biochemical degradation. Wei $\boldsymbol{e t}$. al. (2005) investigated the use of Polh protein as a fusion partner for the expression of the model AMP - halocidin 18-amino-acid subunit (Hal18) in the E. coli. They successfully purified and separated recombinant Hal18 from IBs with a final yield of $30 \%$ with $>90 \%$ purity and demonstrate that Polh can be used to production of AMPs. $\beta$-defensins (Corrales-Garcia et al., 2011) and cathelicidins (human LL-37) are two main families of AMPs which are express on epithelial surface and provide a first line of defense against microbial infection. These AMPs families also play important part in immunomodulatory properties, such as cell migration, proliferation and differentiation (Niyonsaba et al., 2017). Corrales-Garcia et al. (2013) successfully expressed five variants of human $\beta$-defensins (HBD2, HBD3, HBD3-M, HBD2-KLK, HBD3-M-HBD2) in E. coli using two histidine contains vector systems $(\mathrm{pET} 28 \mathrm{a}(+)$ and $\mathrm{pQE} 30)$. While HBD2 and HBD2-KLK were expressed in soluble fractions, HBD3, HBD3-M and HBD3-M-HBD2 were located in the insoluble fraction as inclusion bodies. All variants of HBDs showed activity against pathogenic bacteria, including two strains of Mycobacterium tuberculosis (H37Rv and MDR). Human acidic fibroblast growth factor (haFGF) stimulates repair of delayed healing and is one of the most potential therapeutic growth factors. Delayed healings is usually associated with another serious problem - microbial infection. LL-37 is a cathelicidin-related antimicrobial peptide, which have a critical role in defense against bacterial infection. Shen et al. (2012) designed a novel hybrid LL-37-haFGF gene to obtained fusion protein with functional activities of both. As a host organism was used E. coli and protein was expressed in form of inclusion bodies then purified and refolded. LL-37-haFGF exhibit antimicrobial activity against microorganisms which are associated with wound infection (tab.1) and simultaneously stimulated proliferation of NIH 3T3 cells. Table 1 summarizes the above-mentioned antimicrobial peptides and some of their characteristics. 
Table 1 Summarization of AMPs characteristics

\begin{tabular}{|c|c|c|c|c|c|c|}
\hline AMPs & Size (a.a) & Host org. & Antim. Act. & Solubility & Yield $(\mathrm{mg} / \mathrm{L})$ & references \\
\hline Hepcidin & 25 & E.coli & B. subtilis & insoluble & $16-20$ & Zhang et. al. (2005) \\
\hline \multirow[t]{2}{*}{ MSI-344 } & \multirow[t]{2}{*}{22} & E.coli & E. coli, B. subtilis & \multirow[t]{2}{*}{ insoluble } & \multirow[t]{2}{*}{$\mathrm{NA}^{*}$} & \multirow[t]{2}{*}{ Lee et. al. (2000) } \\
\hline & & $V$. & $\begin{array}{l}\text { S. haemolyticus, S.aureus, } \\
\text { E. coli, V.harveyi }\end{array}$ & & & \\
\hline Crus-likePm & 124 & harveyi & $\begin{array}{l}\text { Aerococcus viridans, } \\
\text { Bacillus megaterium, } \\
\text { Micrococcus luteus }\end{array}$ & $\begin{array}{l}\text { partially } \\
\text { sol. }\end{array}$ & NA & $\begin{array}{l}\text { Amparyup et. al } \\
\text { (2008) }\end{array}$ \\
\hline Dermcidin & 48 & E.coli & $\begin{array}{l}\text { E. coli, S. typhimurium } \\
\text { L. monocytogenes, } S \text {. } \\
\text { aureus, C. albicans }\end{array}$ & insoluble & $\begin{array}{l}2.3 \mathrm{mg} / 10 \mathrm{~g} \text { wet } \\
\text { cells }\end{array}$ & Čipáková et al., 2005 \\
\hline HBD2 & 41 & \multirow{5}{*}{ E.coli } & \multirow{5}{*}{$\begin{array}{l}\text { E. coli, } P . \text { aeruginosa, } S . \\
\text { aureus, } \text { M. tuberculosis }\end{array}$} & soluble & 4 (95\% purity) & \multirow{5}{*}{$\begin{array}{c}\text { Corrales-Garcia et al. } \\
\text { (2013) }\end{array}$} \\
\hline HBD2-KLK & 44 & & & soluble & 3 (92\% purity) & \\
\hline HBD3 & 45 & & & insoluble & 3.4 (90\% purity) & \\
\hline HBD3-M & 46 & & & insoluble & 9.5 (93\% purity) & \\
\hline HBD3-M-HBD2 & 91 & & & insoluble & 5.5 (90\% purity) & \\
\hline LL-37-haFGF & 156 & E.coli & $\begin{array}{l}\text { S. aureus, S.epidermidis, } \\
\text { Pseudomonas aeruginosa, } \\
\text { Klebsiella pneumoniae, } \\
\text { Enterobacter cloacae }\end{array}$ & insoluble & $\begin{array}{l}5.9 \\
(95,43 \% \text { purity) }\end{array}$ & Shen et al. (2012) \\
\hline Hal18 & 18 & E. coli & E. coli $S$. aureus & insoluble & 0.26 (91\% purity) & Wei et. al. (2005) \\
\hline
\end{tabular}

*not available

a.a - number of amino acids

\section{IBS IN BIOMEDICINE}

In addition to their use in AMPs production, IBs have been recently used as biomaterials with potential biomedical applications. This so called "gold waste" can be used for example in tissue engineering, drug or gene delivery and biocatalysis.

\section{Tissue engineering}

The goal of tissue engineering is to regenerate diseased or damaged tissues. In general body cells are attached to extracellular matrix (ECM), which provides structural and biochemical support to surrounding cells. Specific composition of ECM depends on tissue type, but usually includes structural proteins (collagen, elastin), adhesive proteins (fibronectin) and proteoglycans (Mariman and Wang, 2010, Hinds et. al., 2011). Typically, cells must be attached to ECM or other cells to function (proliferate, differentiate). Tissue engineering involves the use of tissue scaffolds (engineered ECM), cells, and biologically active molecules to create functional surrogate tissue or entire organ for a medical purposes. Scaffolds are porous materials that mimics nature ECM and act as templates for tissue regeneration (Zhao et. al., 2013). The employed scaffold should be biodegradable because body cells constantly resorb and replace ECM, so over time they should replace entire implanted scaffold by natural ECM. Scaffolds must by also biocompatible and promote cell functions such as attachment, proliferation and differentiation. Another requirement for scaffold is that it must have pores, within critical range, to facilitate cell migration and transport of nutrients and regulatory factors. Nowadays, there are several materials that are used as scaffolds, including natural polymers (collagen, alginate), synthetic biopolymers (PGA, PLA) and hydrogels (O'Brien, 2011).

For efficient cell attachment and colonization of scaffold surface is necessary to create correct tissue structure. In recent years, many studies have confirmed that IBs can be used as biocompatible and biodegradable materials for scaffold surface decoration. There is still more and more evidences that IB materials can be used as particulate biomaterials that dramatically support cell colonization and proliferation without any sign of cytotoxicity (Diez-Gil et al., 2010, GarciaFruitos et. al., 2009). In one study, Seras- Franzoso et al. (2012) showed that mammalian cell expansion of IB-decorated scaffolds is a result of two independent processes, namely cell attachment and mechanical stimulation of cell division, which are triggered differently by IBs. While cell attachment is dependent on IBs variant, stimulation off proliferation, which involves the activation of the ERK pathway is based on the activity of filopodia-like sensing probes. Seras-Franzoso et al. (2013) explored how IBs decorated novel 3D porous scaffolds (constructed by polylactic acid, polycaprolactone or chitosan) promote intracellular delivery of biologically active proteins. They successfully delivered proteins up to more than $80 \%$ of the colonizing cells, depending on the scaffold type.

\section{Drug and gene delivery}

In recent years, there has been a growing interest in the development of nano drug delivery systems (DDS) that are able to deliver embedded genes or protein drugs into mammalian cells in the form of nanopils. The purpose of these nanomedical drug delivery approaches is to provide long-term local treatment to patients. Suitable materials for nanopills construction, must meet a number of requirements, such as bioavailability, biocompatibility, biodegradability and low toxicity (Yin $\boldsymbol{e t}$. $\boldsymbol{a l}$., 2017). Despite the fact that a number of materials are known to meet these criteria (micelles, liposomes, nanotubes), their low specificity and difficult large-scale production attracts more and more attention to the IBs as a potential therapeutic agents (Villaverde et. al., 2012). Biological activity, nanomechanical properties, biocompatibility and slow release of protein therapeutics in aqueous conditions present the main advantages of IBs nanopills Moreover, IBs made up of proteins of therapeutic interest are able to penetrate cells membranes and thus are capable to reach the cytoplasm as well as the nucleus. A growing number of studies confirm that IBs nanopills are suitable for protein replacement and other therapies (Thwaite $\boldsymbol{e t}$. al., 2018, Talafová $\boldsymbol{e t}$ al., 2013), even show potential to increase cancer treatment efficiency (Unzueta et. al., 2017, Unzueta et. al., 2018, Céspedes et. al., 2016). Vázquez et.al. (2012) studied effects of IBs containing therapeutically potential enzymes and proteins (chaperone Hsp70, dihydrofolate reductase, catalase and the growth factor leukemia inhibitory factor) on variously injured cell lines. In all four cases these proteins had positive physiological effects on the treated cells, specifically they enhance cell survival and/or proliferation under stress conditions. Fibroblas growth factor-2 (FGF-2) is a FGF family member involved in a variety of biological processes such as embryonic development, cell proliferation, cell migration, morphogenesis, tissue repair, tumor growth and invasion (Bikfalvi $\boldsymbol{e t}$. al., 1997). Seras-Franzoso et. al. (2014) characterize effect of temperature on the structure and biological activity (promotion of cell proliferation and the induction of cell differentiation) of FGF-2 IBs overexpressed in E. coli. They used two temperatures, namely 25 and $37^{\circ} \mathrm{C}$. Protein particles produced at a lower temperature were nearly $100 \mathrm{~nm}$ larger than that formed at $37{ }^{\circ} \mathrm{C}$ and the recovery of soluble proteins was higher in the IBs formed at $25{ }^{\circ} \mathrm{C}$. Taken together, both temperature formed IBs, but higher activity was observed for the IBs produced at $25{ }^{\circ} \mathrm{C}$. In another study, Liovic at. al. (2012) demonstrate that inclusion bodies can be used to deliver complex proteins into epithelial cells. As an example they choose keratin 14 (K14), polymeric cytoskeletal protein. To be function and build filaments, monomeric K14 needs first to dimerize and form heterodimers with keratin 5 (K5). They use cDNA plasmid containing EYFP (enhanced yellow fluorescent protein) labeled keratin 5 as a reporter. They perform several experiments on SW13 cells (human adrenal carcinoma cell line) that normally do not express keratin and prove that K14 IBs contain functional $\mathrm{K} 14$, moreover these IBs also did not appear to be cytotoxic.

\section{Biocatalysis}

The use of enzymes in biocatalysis have a broad applications in various fields of interest, including pharmaceutical and chemical industry, as well as biomedical, cosmetic and diagnostic applications (Adrio and Demain, 2014). Soluble enzymes present the most commonly used form of enzymes in biocatalysis and their use is usually associated with the immobilization on the surface of an insoluble carrier (Mateo et. al., 2007). These process on the one hand increase life time and protein stability but on the other hand decrease protein activity. IBs have been also explored as biocatalysts for many enzymatic processes. Finding that formation of bacterial IBs did not completely inactivate enzymes (Garcia- 
Fruitos et.al., 2005) together with their self-immobilized character makes IBs an interesting material for efficient catalysis. The potential of IBs for biocatalytic purposes supports various studies. Nahalka, et. al (2008) used IBs of sialic acid aldolase for production of sialic acid (neuraminic acid, Neu5A). Sialic acid is a sugar with nine-carbon backbone and can be usually found on the surface of vertebrate cells, where modulate many of physiological and pathological processes (Varki, 2008). IBs can be directly recovered by centrifugation, but nowadays there is several approaches that simplify and streamline separation. Nahalka et. $\boldsymbol{a l}$. (2006) immobilized catalytically active IBs of polyphosphate kinase in agar/ $/ \mathrm{TiO}_{2}$ beads. They used these bioenergy beads as rechargeable supply for synthesis of ATP from ADP and polyphosphates, with the yield of ATP gradually drops from initially concentration $55 \%$ to about $30 \%$ after 17 conversion cycles. Köszagová et. al. (2018) introduced alternative separation approach and used iron oxide particles to create magnetically modified active IBs. As example they used three magnetically modified proteins: green fluorescent protein (GFP), sialic acid aldolase (SAA), and UDP-glucose pyrophosphorylase. In all cases the magnetization of IBs enabling an easier separation process using a magnetic field and stabilize the repetitive use of the inclusion bodies in comparison with centrifugation.

\section{CONCLUSION}

In conclusion, widely accepted paradigm that IBs of recombinant protein represent a waste inactivate product, has been challenged in recent years. Instead, the newly described properties of IBs and the latest studies strongly supports the use of IBs in various fields. However, further researches are still needed to fully clarify the potential of IBs in emerging biotechnological applications.

Acknowledgments: Work was supported by the projects VEGA 2/0058/17 and APVV-15-0227; by the Research and Development Operational Programme, ITMS 26220120054

\section{REFERENCES}

Achmüller, C., Kaar, W., Ahrer, K., Wechner, P., Hahn, R., Werther, F., ... Auer, B. (2007). Npro fusion technology to produce proteins with authentic $\mathrm{N}$ termini in E. coli. Nature Methods, 4(12), 1037-1043. https://doi.org/10.1038/nmeth1116

Adrio, J., \& Demain, A. (2014). Microbial Enzymes: Tools for Biotechnological Processes. Biomolecules, 4(1), 117-139. https://doi.org/10.3390/biom4010117 Amparyup, P., Kondo, H., Hirono, I., Aoki, T., \& Tassanakajon, A. (2008). Molecular cloning, genomic organization and recombinant expression of a crustin-like antimicrobial peptide from black tiger shrimp Penaeus monodon. $\begin{array}{llll}\text { Molecular } & \text { Immunology, 45(4), 1085-1093. }\end{array}$ https://doi.org/10.1016/j.molimm.2007.07.031

Aoki, W., \& Ueda, M. (2013). Characterization of Antimicrobial Peptides toward the Development of Novel Antibiotics. Pharmaceuticals, 6(8), 1055-1081 https://doi.org/10.3390/ph6081055

Arié, J.-P., Miot, M., Sassoon, N., \& Betton, J.-M. (2006). Formation of active inclusion bodies in the periplasm ofEscherichia coli. Molecular Microbiology, 62(2), 427-437. https://doi.org/10.1111/j.1365-2958.2006.05394.x

Bahar, A., \& Ren, D. (2013). Antimicrobial Peptides. Pharmaceuticals, 6(12), 1543-1575. https://doi.org/10.3390/ph6121543

Baldi, L., Hacker, D. L., Adam, M., \& Wurm, F. M. (2007). Recombinant protein production by large-scale transient gene expression in mammalian cells: state of the art and future perspectives. Biotechnology Letters, 29(5), 677-684. https://doi.org/10.1007/s10529-006-9297-y

Bikfalvi, A., Klein, S., Pintucci, G., \& Rifkin, D. B. (1997). Biological Roles of Fibroblast Growth Factor-2*. Endocrine Reviews, 18(1), 26-45 https://doi.org/10.1210/edrv.18.1.0292

Bogomolovas, J., Simon, B., Sattler, M., \& Stier, G. (2009). Screening of fusion partners for high yield expression and purification of bioactive viscotoxins. Protein Expression and Purification, 64(1), 16-23. https://doi.org/10.1016/i.pep.2008.10.003

Boutigny, S., Sautron, E., Frelet-Barrand, A., Moyet, L., Salvi, D., Rolland, N., \& Seigneurin-Berny, D. (2014). Functional Expression of Plant Membrane Proteins in Lactococcus lactis. Insoluble Proteins, 147-165. https://doi.org/10.1007/978-1 4939-2205-5_8

Bowden, G. A., Paredes, A. M., \& Georgiou, G. (1991). Structure and Morphology of Protein Inclusion Bodies in Escherichia Coli. Nature Biotechnology, 9(8), 725-730. https://doi.org/10.1038/nbt0891-725

Brogden, K. A. (2005). Antimicrobial peptides: pore formers or metabolic inhibitors in bacteria? Nature Reviews Microbiology, 3(3), 238-250. https://doi.org/10.1038/nrmicro1098

Cano-Garrido, O., Sánchez-Chardi, A., Parés, S., Giró, I., Tatkiewicz, W. I. Ferrer-Miralles, N., ... Garcia-Fruitós, E. (2016). Functional protein-based nanomaterial produced in microorganisms recognized as safe: A new platform for $\begin{array}{llll}\text { biotechnology. } & \text { Acta } & \text { Biomaterialia, 230-239. }\end{array}$ https://doi.org/10.1016/j.actbio.2016.07.038
Carrió, M., González-Montalbán, N., Vera, A., Villaverde, A., \& Ventura, S. (2005). Amyloid-like Properties of Bacterial Inclusion Bodies. Journal of Molecular Biology, 347(5), $1025-1037$.

https://doi.org/10.1016/j.jmb.2005.02.030

Castellanos-Mendoza, A., Castro-Acosta, R. M., Olvera, A., Zavala, G., Mendoza-Vera, M., García-Hernández, E., ... Valdez-Cruz, N. A. (2014) Influence of $\mathrm{pH}$ control in the formation of inclusion bodies during production of recombinant sphingomyelinase-D in Escherichia coli. Microbial Cell Factories, 13(1). https://doi.org/10.1186/s12934-014-0137-9

Céspedes, M. V., Fernández, Y., Unzueta, U., Mendoza, R., Seras-Franzoso, J., Sánchez-Chardi, A., ... Villaverde, A. (2016). Bacterial mimetics of endocrine secretory granules as immobilized in vivo depots for functional protein drugs. Scientific Reports, 6(1). https://doi.org/10.1038/srep35765

Ciechanover, A., \& Kwon, Y. T. (2015). Degradation of misfolded proteins in neurodegenerative diseases: therapeutic targets and strategies. Experimental \& Molecular Medicine, 47(3), e147-e147. https://doi.org/10.1038/emm.2014.117

Ciechanover, A., \& Kwon, Y. T. (2017). Protein Quality Control by Molecular Chaperones in Neurodegeneration. Frontiers in Neuroscience, 11 https://doi.org/10.3389/fnins.2017.00185

Contreras-Gómez, A., Sánchez-Mirón, A., García-Camacho, F., Molina-Grima, E., \& Chisti, Y. (2013). Protein production using the baculovirus-insect cell expression system. Biotechnology Progress, 30(1), 1-18. https://doi.org/10.1002/btpr.1842

Corrales-Garcia, L. L., Possani, L. D., \& Corzo, G. (2010). Expression systems of human $\beta$-defensins: vectors, purification and biological activities. Amino Acids, 40(1), 5-13. https://doi.org/10.1007/s00726-010-0493-7

Corrales-Garcia, L., Ortiz, E., Castañeda-Delgado, J., Rivas-Santiago, B., \& Corzo, G. (2013). Bacterial expression and antibiotic activities of recombinant variants of human $\beta$-defensins on pathogenic bacteria and $M$. tuberculosis Protein Expression and Purification, 89(1), 33-43. https://doi.org/10.1016/j.pep.2013.02.007

De Groot, N. S., \& Ventura, S. (2006). Effect of temperature on protein quality in bacterial inclusion bodies. FEBS Letters, 580(27), 6471-6476. https://doi.org/10.1016/j.febslet.2006.10.071

Diener, M., Kopka, B., Pohl, M., Jaeger, K.-E., \& Krauss, U. (2015). Fusion of a Coiled-Coil Domain Facilitates the High-Level Production of Catalytically Active Enzyme Inclusion Bodies. ChemCatChem, 8(1), 142-152 https://doi.org/10.1002/cctc.201501001

Díez-Gil, C., Krabbenborg, S., García-Fruitós, E., Vazquez, E., RodríguezCarmona, E., Ratera, I., ... Veciana, J. (2010). The nanoscale properties of bacterial inclusion bodies and their effect on mammalian cell proliferation. Biomaterials, 31(22),

https://doi.org/10.1016/j.biomaterials.2010.04.008

Doron, L., Segal, N., \& Shapira, M. (2016). Transgene Expression in Microalgae-From Tools to Applications. Frontiers in Plant Science, 7. https://doi.org/10.3389/fpls.2016.00505

Fahnert, B., Lilie, H., \& Neubauer, P. (2004). Inclusion Bodies: Formation and Utilisation. Advances in Biochemical Engineering/Biotechnology, 93-142. https://doi.org/10.1007/b93995

Felício, M. R., Silva, O. N., Gonçalves, S., Santos, N. C., \& Franco, O. L. (2017) Peptides with Dual Antimicrobial and Anticancer Activities. Frontiers in Chemistry, 5. https://doi.org/10.3389/fchem.2017.00005

Garcia-Fruitos, E., Gonzalez-Montalban, N., Morell, M., Vera, A., Ferraz, R. M., Atís, A., Ventura, S., Villaverde, A. (2005). Aggregation as bacterial inclusion bodies does not imply inactivation of enzymes and fluorescent proteins. Microb. Cell. Fact. 4, 27. https://doi.org/10.1186/1475-2859-4-27

García-Fruitós, E., Rodríguez-Carmona, E., Díez-Gil, C., Ferraz, R. M., Vázquez, E., Corchero, J. L., ... Villaverde, A. (2009). Surface Cell Growth Engineering Assisted by a Novel Bacterial Nanomaterial. Advanced Materials, 21(42), 42494253. https://doi.org/10.1002/adma.200900283

García-Fruitós, E., Seras-Franzoso, J., Vazquez, E., \& Villaverde, A. (2010) Tunable geometry of bacterial inclusion bodies as substrate materials for tissue engineering. Nanotechnology, 21(20), 205101. https://doi.org/10.1088/09574484/21/20/205101

Gong, Y., Hu, H., Gao, Y., Xu, X., \& Gao, H. (2011). Microalgae as platforms for production of recombinant proteins and valuable compounds: progress and prospects. Journal of Industrial Microbiology \& Biotechnology, 38(12), 1879 1890. https://doi.org/10.1007/s10295-011-1032-6

Grune, T., Jung, T., Merker, K., \& Davies, K. J. A. (2004). Decreased proteolysis caused by protein aggregates, inclusion bodies, plaques, lipofuscin, ceroid, and "aggresomes" during oxidative stress, aging, and disease. The International Journal of Biochemistry \& Cell Biology, 36(12), 2519-2530. https://doi.org/10.1016/i.biocel.2004.04.020

Gwyer Findlay, E., Currie, S. M., \& Davidson, D. J. (2013). Cationic Host Defence Peptides: Potential as Antiviral Therapeutics. BioDrugs, 27(5), 479-493 https://doi.org/10.1007/s40259-013-0039-0

Hadj Sassi, A., Trigui-Lahiani, H., Abdeljalil, S., \& Gargouri, A. (2017) Enhancement of solubility, purification and inclusion-bodies-refolding of an active pectin lyase from Penicillium occitanis expressed in Escherichia coli. 
International Journal of Biological Macromolecules, 95, 256-262. https://doi.org/10.1016/i.ijbiomac.2016.11.036

Harris, P. W. R., Yang, S.-H., Molina, A., López, G., Middleditch, M., \& Brimble, M. A. (2014). Plant Antimicrobial Peptides Snakin-1 and Snakin-2: Chemical Synthesis and Insights into the Disulfide Connectivity. Chemistry - A European Journal, 20(17), 5102-5110. https://doi.org/10.1002/chem.201303207 Hinds, S., Bian, W., Dennis, R. G., \& Bursac, N. (2011). The role of extracellular matrix composition in structure and function of bioengineered skeletal muscle. Biomaterials, $32(14)$

$3575-3583$. https://doi.org/10.1016/i.biomaterials.2011.01.062

Hou, J., Tyo, K. E. J., Liu, Z., Petranovic, D., \& Nielsen, J. (2012). Metabolic engineering of recombinant protein secretion by Saccharomyces cerevisiae. FEMS Yeast Research, 12(5), 491-510. https://doi.org/10.1111/j.15671364.2012.00810.x

Huang, Z., Zhang, C., Chen, S., Ye, F., \& Xing, X.-H. (2013). Active inclusion bodies of acid phosphatase PhoC: aggregation induced by GFP fusion and activities modulated by linker flexibility. Microbial Cell Factories, 12(1), 25. https://doi.org/10.1186/1475-2859-12-25

Jenssen, H., Hamill, P., \& Hancock, R. E. W. (2006). Peptide Antimicrobial Agents. Clinical Microbiology Reviews, 19(3), 491-511. https://doi.org/10.1128/cmr.00056-05

Kaar, W., Ahrer, K., Dürauer, A., Greinstetter, S., Sprinzl, W., Wechner, P., .. Jungbauer, A. (2009). Refolding of Nprofusion proteins. Biotechnology and Bioengineering, 104(4), 774-784. https://doi.org/10.1002/bit.22432

Khan, K. H. (2013). Gene Expression in Mammalian Cells and its Applications. Advanced Pharmaceutical Bulletin, 3(2), 257-263. http://doi.org/10.5681/apb.2013.042

Kopito, R. R. (2000). Aggresomes, inclusion bodies and protein aggregation Trends in Cell Biology, 10(12), 524-530. https://doi.org/10.1016/s0962 8924(00)01852-3

Kost, T. A., Condreay, J. P., \& Jarvis, D. L. (2005). Baculovirus as versatile vectors for protein expression in insect and mammalian cells. Nature Biotechnology, 23(5), 567-575. https://doi.org/10.1038/nbt1095

Koszagova, R., Krajcovic, T., Palencarova-Talafova, K., Patoprsty, V., Vikartovska, A., Pospiskova, K., ... Nahalka, J. (2018). Magnetization of active inclusion bodies: comparison with centrifugation in repetitive biotransformations. Microbial Cell Factories, 17(1). https://doi.org/10.1186/s12934-018-0987-7

Lee, J. H., Kim, J. H., Hwang, S. W., Lee, W. J., Yoon, H. K., Lee, H. S., \& Hong, S. S. (2000). High-Level Expression of Antimicrobial Peptide Mediated by a Fusion Partner Reinforcing Formation of Inclusion Bodies. Biochemical and Biophysical Research Communications, 277(3), 575-580. https://doi.org/10.1006/bbrc.2000.3712

Li, J. F., Zhang, J., Zhang, Z., Kang, C. T., \& Zhang, S. Q. (2010). SUMO Mediating Fusion Expression of Antimicrobial Peptide CM4 from two Joined Genes in Escherichia coli. Current Microbiology, 62(1), 296-300. https://doi.org/10.1007/s00284-010-9705-3

Li, Y. (2011). Recombinant production of antimicrobial peptides in Escherichia coli: A review. Protein Expression and Purification, 80(2), 260-267. https://doi.org/10.1016/j.pep.2011.08.001

Liovic, M., Ozir, M., Zavec, A., Peternel, S., Komel, R., \& Zupancic, T. (2012). Inclusion bodies as potential vehicles for recombinant protein delivery into epithelial cells. Microbial Cell Factories, 11(1), 67. https://doi.org/10.1186/1475. 2859-11-67

Ma, Q., Yu, Z., Han, B., Wang, Q., \& Zhang, R. (2012). Expression and purification of lacticin $Q$ by small ubiquitin-related modifier fusion in Escherichia coli. The Journal of Microbiology, 50(2), 326-331. https://doi.org/10.1007/s12275-012-1425-x

Manuell, A. L., Beligni, M. V., Elder, J. H., Siefker, D. T., Tran, M., Weber, A., Mayfield, S. P. (2007). Robust expression of a bioactive mammalian protein in Chlamydomonas chloroplast. Plant Biotechnology Journal, 5(3), 402-412. https://doi.org/10.1111/j.1467-7652.2007.00249.x

Margreiter, G., Messner, P., Caldwell, K. D., \& Bayer, K. (2008). Size characterization of inclusion bodies by sedimentation field-flow fractionation. $\begin{array}{llll}\text { Journal of } & \text { Biotechnology, } & \text { 138(3-4), } & \end{array}$ https://doi.org/10.1016/i.jbiotec.2008.07.1995

Mariman, E. C. M., \& Wang, P. (2010). Adipocyte extracellular matrix composition, dynamics and role in obesity. Cellular and Molecular Life Sciences, 67(8), 1277-1292. https://doi.org/10.1007/s00018-010-0263-4

Markossian, K. A., \& Kurganov, B. I. (2004). Protein Folding, Misfolding, and Aggregation. Formation of Inclusion Bodies and Aggresomes. Biochemistry (Moscow), 69(9), 971-984. https://doi.org/10.1023/b:biry.0000043539.07961.4c Mateo, C., Palomo, J. M., Fernandez-Lorente, G., Guisan, J. M., \& FernandezLafuente, R. (2007). Improvement of enzyme activity, stability and selectivity via immobilization techniques. Enzyme and Microbial Technology, 40(6), 14511463. https://doi.org/10.1016/i.enzmictec. 2007.01.018

Miot, M., Betton, J.M. (2004). Protein quality control in the bacterial periplasm. Microbial Cell Factories, 3(1), 4. https://doi.org/10.1186/1475-2859-3-4

Mohammadian, A., Kaghazian, H., Kavianpour, A., \& Jalalirad, R. (2018). Solubilization of inclusion body proteins using low and very low concentrations of chemicals: implications of novel combined chemical treatment designs in enhancement of post-solubilization target protein purity and biological activity. Journal of Chemical Technology \& Biotechnology, 93(6), 1579-1587. https://doi.org/10.1002/jctb.5525

Moreno-Gonzalez, I., \& Soto, C. (2011). Misfolded protein aggregates: Mechanisms, structures and potential for disease transmission. Seminars in Cell $\begin{array}{llll}\text { \& Developmental } & \text { Biology, } & \text { 22(5), } & 482-487\end{array}$ https://doi.org/10.1016/j.semcdb.2011.04.002

Nahálka, J., Gemeiner, P., Bučko, M., \& Wang, P. G. (2006). Bioenergy Beads A Tool for Regeneration of ATP/NTP in Biocatalytic Synthesis. Artificial Cells, Blood Substitutes, and Biotechnology, 34(5), 515-521. https://doi.org/10.1080/10731190600862886

Nahálka, J., Vikartovská, A., \& Hrabárová, E. (2008). A crosslinked inclusion body process for sialic acid synthesis. Journal of Biotechnology, 134(1-2), 146153. https://doi.org/10.1016/j.jbiotec.2008.01.014

Nettleship, J. E., Assenberg, R., Diprose, J. M., Rahman-Huq, N., \& Owens, R. J. (2010). Recent advances in the production of proteins in insect and mammalian cells for structural biology. Journal of Structural Biology, 172(1), 55-65. https://doi.org/10.1016/j.jsb.2010.02.006

Neubauer, P., Fahnert, B., Lilie, H., \& Villaverde, A. (n.d.). Protein Inclusion Bodies in Recombinant Bacteria. Microbiology Monographs, 237-292. https://doi.org/10.1007/3-540-33774-1_9

Nguyen, L. T., Haney, E. F., \& Vogel, H. J. (2011). The expanding scope of antimicrobial peptide structures and their modes of action. Trends in Biotechnology, 29(9), 464-472. https://doi.org/10.1016/j.tibtech.2011.05.001

Niyonsaba, F., Kiatsurayanon, C., Chieosilapatham, P., \& Ogawa, H. (2017). Friends or Foes? Host defense (antimicrobial) peptides and proteins in human skin diseases. Experimental Dermatology, 26(11), 989-998. https://doi.org/10.1111/exd.13314

O’Brien, F. J. (2011). Biomaterials \& scaffolds for tissue engineering. Materials Today, 14(3), 88-95. https://doi.org/10.1016/s1369-7021(11)70058-x

Peternel, Š., \& Komel, R. (2011). Active Protein Aggregates Produced in Escherichia coli. International Journal of Molecular Sciences, 12(11), 82758287. https://doi.org/10.3390/ijms12118275

Quinn, K., Henriques, M., Parker, T., Slutsky, A. S., \& Zhang, H. (2008). Human neutrophil peptides: a novel potential mediator of inflammatory cardiovascular diseases. American Journal of Physiology-Heart and Circulatory Physiology, 295(5), H1817-H1824. https://doi.org/10.1152/ajpheart.00472.2008

Rinas, U., Garcia-Fruitós, E., Corchero, J. L., Vázquez, E., Seras-Franzoso, J., \& Villaverde, A. (2017). Bacterial Inclusion Bodies: Discovering Their Better Half Trends in Biochemical Sciences, 42(9), 726-737. https://doi.org/10.1016/j.tibs.2017.01.005

Ross, C. A., \& Poirier, M. A. (2004). Protein aggregation and neurodegenerative disease. Nature Medicine, 10(S7), S10-S17. https://doi.org/10.1038/nm1066 Rueda, F., Gasser, B., Sánchez-Chardi, A., Roldán, M., Villegas, S., Puxbaum, V., ... Villaverde, A. (2016). Functional inclusion bodies produced in the yeast Pichia pastoris. Microbial Cell Factories, 15(1). https://doi.org/10.1186/s12934. 016-0565-9

Sabate, R., de Groot, N. S., \& Ventura, S. (2010). Protein folding and aggregation in bacteria. Cellular and Molecular Life Sciences, 67(16), 26952715. https://doi.org/10.1007/s00018-010-0344-4

Seras-Franzoso, J., Díez-Gil, C., Vazquez, E., García-Fruitós, E., Cubarsi, R., Ratera, I., ... Villaverde, A. (2012). Bioadhesiveness and efficient mechanotransduction stimuli synergistically provided by bacterial inclusion bodies as scaffolds for tissue engineering. Nanomedicine, 7(1), 79-93. https://doi.org/10.2217/nnm.11.83

Seras-Franzoso, J., Peebo, K., García-Fruitós, E., Vázquez, E., Rinas, U., \& Villaverde, A. (2014). Improving protein delivery of fibroblast growth factor-2 from bacterial inclusion bodies used as cell culture substrates. Acta Biomaterialia, 10(3), 1354-1359. https://doi.org/10.1016/j.actbio.2013.12.021

Seras-Franzoso, J., Steurer, C., Roldán, M., Vendrell, M., Vidaurre-Agut, C., Tarruella, A., ... Villaverde, A. (2013). Functionalization of 3D scaffolds with protein-releasing biomaterials for intracellular delivery. Journal of Controlled Release, 171(1), 63-72. https://doi.org/10.1016/j.jconrel.2013.06.034

Shen, J., Lu, X., Jin, X., Ding, J., Li, X., Mei, H., ... Zhu, J. (2012). Expression of a novel dual-functional protein - The antimicrobial peptide LL-37 fused with human acidic fibroblast growth factor in Escherichia coli. Protein Expression and Purification, 81(1), 119-125. https://doi.org/10.1016/i.pep.2011.09.007

Spolaore, P., Joannis-Cassan, C., Duran, E., \& Isambert, A. (2006). Commercial applications of microalgae. Journal of Bioscience and Bioengineering, 101(2) 87-96. https://doi.org/10.1263/jbb.101.87

Steinstraesser, L., Koehler, T., Jacobsen, F., Daigeler, A., Goertz, O., Langer, S., . Hirsch, T. (2008). Host Defense Peptides in Wound Healing. Molecular Medicine, 14(7-8), 528-537. https://doi.org/10.2119/2008-00002.steinstraesser

Talafová, K., Hrabárová, E., Chorvát, D., \& Nahálka, J. (2013). Bacterial inclusion bodies as potential synthetic devices for pathogen recognition and a therapeutic substance release. Microbial Cell Factories, 12(1), 16 https://doi.org/10.1186/1475-2859-12-16

Thwaite, R., Ji, J., Torrealba, D., Coll, J., Sabés, M., Villaverde, A., \& Roher, N. (2018). Protein Nanoparticles Made of Recombinant Viral Antigens: A 
Promising Biomaterial for Oral Delivery of Fish Prophylactics. Frontiers in Immunology, 9. https://doi.org/10.3389/fimmu.2018.01652

Unzueta, U., Cespedes, M. V., Sala, R., Alamo, P., Sánchez-Chardi, A. Pesarrodona, M., ... Seras-Franzoso, J. (2018). Release of targeted protein nanoparticles from functional bacterial amyloids: A death star-like approach Journal of Controlled Release, 279, 29-39. https://doi.org/10.1016/i.jconrel.2018.04.004

Unzueta, U., Seras-Franzoso, J., Céspedes, M. V., Saccardo, P., Cortés, F., Rueda, F., ... Villaverde, A. (2016). Engineering tumor cell targeting in nanoscale amyloidal materials. Nanotechnology, 28(1), 015102. https://doi.org/10.1088/0957-4484/28/1/015102

Upadhyay, V., Singh, A., Jha, D., Singh, A., \& Panda, A. K. (2016). Recovery of bioactive protein from bacterial inclusion bodies using trifluoroethanol as solubilization agent. Microbial Cell Factories, 15(1). https://doi.org/10.1186/s12934-016-0504-9

Varki, A. (2008). Sialic acids in human health and disease. Trends in Molecular Medicine, 14(8), 351-360. https://doi.org/10.1016/j.molmed.2008.06.002

Vázquez, E., Corchero, J. L., Burgueño, J. F., Seras-Franzoso, J., Kosoy, A., Bosser, R., ... Villaverde, A. (2012). Functional Inclusion Bodies Produced in Bacteria as Naturally Occurring Nanopills for Advanced Cell Therapies. Advanced Materials, 24(13), 1742-1747. https://doi.org/10.1002/adma.201104330

Villaverde, A., Carrio, M.M. (2003). Protein aggregation in recombinant bacteria: biological role of inclusion bodies. Biotechnol. Lett. 25 (17), 1385-1395. https://doi.org/10.1023/a:1025024104862

Villaverde, A., García-Fruitós, E., Rinas, U., Seras-Franzoso, J., Kosoy, A., Corchero, J., \& Vazquez, E. (2012). Packaging protein drugs as bacterial inclusion bodies for therapeutic applications. Microbial Cell Factories, 11(1), 76 https://doi.org/10.1186/1475-2859-11-76

Wang, L. (2009). Towards revealing the structure of bacterial inclusion bodies Prion, 3(3), 139-145. https://doi.org/10.4161/pri.3.3.9922

Wang, X., Zhou, B., Hu, W., Zhao, Q., \& Lin, Z. (2015). Formation of active inclusion bodies induced by hydrophobic self-assembling peptide GFIL8. Microbial Cell Factories, 14(1). https://doi.org/10.1186/s12934-015-0270-0

Wu, W., Xing, L., Zhou, B., \& Lin, Z. (2011). Active protein aggregates induced by terminally attached self-assembling peptide ELK16 in Escherichia coli. Microbial Cell Factories, 10(1), 9. https://doi.org/10.1186/1475-2859-10-9

Yin, L., Yuvienco, C., \& Montclare, J. K. (2017). Protein based therapeutic delivery agents: Contemporary developments and challenges. Biomaterials, 134 91-116. https://doi.org/10.1016/j.biomaterials.2017.04.036

Zhang, H., Yuan, Q., Zhu, Y., \& Ma, R. (2005). Expression and preparation of recombinant hepcidin in Escherichia coli. Protein Expression and Purification, 41(2), 409-416. https://doi.org/10.1016/j.pep.2005.03.003

Zhang, L., \& Gallo, R. L. (2016). Antimicrobial peptides. Current Biology, 26(1) R14-R19. https://doi.org/10.1016/i.cub.2015.11.017

Zhao, C., Tan, A., Pastorin, G., \& Ho, H. K. (2013). Nanomaterial scaffolds for stem cell proliferation and differentiation in tissue engineering. Biotechnology Advances, 31(5), 654-668. https://doi.org/10.1016/j.biotechadv.2012.08.001 